\title{
Article
}

\section{The Evolution of the Police Analyst and the Influence of Evidence-Based Policing}

Keay, Scott and Kirby, Stuart

Available at http://clok.uclan.ac.uk/20420/

Keay, Scott ORCID: 0000-0001-6489-3010 and Kirby, Stuart ORCID: 00000002-3049-1248 (2018) The Evolution of the Police Analyst and the Influence of Evidence-Based Policing. Policing: A Journal of Police and Practice, 12 (3). pp. 265-276. ISSN 1752-4512

It is advisable to refer to the publisher's version if you intend to cite from the work. http://dx.doi.org/10.1093/police/pax065

For more information about UCLan's research in this area go to http://www.uclan.ac.uk/researchgroups/ and search for <name of research Group>.

For information about Research generally at UCLan please go to http://www.uclan.ac.uk/research/

All outputs in CLoK are protected by Intellectual Property Rights law, including Copyright law. Copyright, IPR and Moral Rights for the works on this site are retained by the individual authors and/or other copyright owners. Terms and conditions for use of this material are defined in the policies page. 


\section{The Evolution of the Police Analyst and the Influence of Evidence-Based Policing}

ABSTRACT

The National Intelligence Model (NIM), implemented in the UK during 2000, was at the centre of the police reform agenda and catalyst for a growth in the number of police analyst posts within UK police agencies. Since then commentators have questioned whether the role of the police analyst has lived up to expectation. This has been an interesting development considering that crime analysis is an essential component in influencing policing activity. This study explores the status of police analysts in the UK and outlines why the position may have been undermined. However, it also asks whether the growing emphasis towards evidence-based policing (EBP) provides a renewed opportunity for police analysts and the integration of crime analysis. It argues the integration of EBP (interpreted in its widest sense) could be an evolutionary step in finally establishing the police analyst as a true law enforcement professional. In doing so, it examines the role of the analyst both as a producer of information and as a bridge to partners, including academia, to assist in coproduction of rigorous analysis that can be used to direct policing resources and influence policy.

\section{INTRODUCTION}

The Kansas City Preventative Patrol experiment (Kelling, 1974) was at the start of a series of proactive approaches to policing. Increased intellectual engagement coupled with advances in technology to improve data management and communication, promised more effective methods to tackle crime and disorder. Of these, Community Policing (Skolnick \& Bayley, 1988), Problem Oriented Policing (Goldstein, 1979) and Intelligence Led Policing (Audit Commission, 1993) were perhaps the most prominent. Indeed, Intelligence led Policing, morphed into many international derivatives (i.e. Compstat) and, during 2000 , led to the UK National Intelligence Model (NIM). This model unambiguously placed police analysts at the centre of police professionalization, generating new standards of analysis for police data. However, many commentators have questioned whether the role of police analyst delivered its potential. 
This study begins by exploring the status of police analysts and analysis within the UK. It also highlights the most recent policing approach - evidence based policing - and asks whether it provides a renewed opportunity to establish the police analyst and to improve standards of crime analysis, as originally envisaged by the NIM. To do this, research for this paper incorporated two surveys: one survey to determine the level of analyst numbers within UK police forces following austerity cuts, and a second survey that sought the views of existing analysts regarding their knowledge and use of EBP in their day-to-day role. This paper presents the findings from these surveys and concludes that there is scope for improving crime analysis by incorporating more rigorous analytical techniques, such as evidence based policing, but police forces also need to recognise the value that the analyst role can offer and use the analyst skills more wisely.

\section{LITERATURE REVIEW}

\section{The emergence of the NIM and the Police Analyst}

The political environment of the UK in the 1990's emphasized what became known as the three E's: effectiveness, efficiency, and economy. At this time public sector organisations came under increased scrutiny to maximize good practice and reduce inefficiencies. Specifically, the Police were urged to concentrate on the small number of people who either committed or suffered a disproportionate amount of crime and anti-social behaviour. By making repeat victims less vulnerable and targeting persistent offenders, it was thought the greatest level of harm could be reduced in the most efficient way. Whilst this logic was embraced by UK Police Forces, implementation was intermittent and varied. Concerned by this lack of progress the UK government urged Chief Police Officers to accelerate and standardize the approach. Responding, the (then) British Association of Chief Police Officers (ACPO) set up a working group to articulate an intelligence process and enshrine it in policy. The UK National Intelligence Model was implemented in 2000, and as John and Maguire (2003, p. 38) explained:

'[The NIM] is in essence a business model - a means of organizing knowledge and information in such a way that the best possible decisions can be made about how to deploy resources, that actions can be co-ordinated within and between different levels of policing, and that lessons are continually learnt and 
fed back into the system.'

The model provided a coherent minimum standard for intelligence processes and terminology, which promoted collaboration between, and within, police forces. It also provided a more transparent decision-making process through the delivery of a standard set of intelligence products ${ }^{1}$, which contained a variety of analytical techniques (NCIS, 2000).

The documentation provided by the working group proposed four key intelligence products (strategic assessment, tactical assessment, target profiles, and problem profiles). These were supported by nine analytic techniques, including: Crime Pattern Analysis; Network Analysis; Criminal Business Profile; Market Profiles; Target Profile Analysis; Risk Analysis; Demographic/ Social Trends Analysis; Operational Intelligence Assessment; and Results Analysis (NCIS, 2000). The products fed into two Tasking and Co-ordinating Groups (strategic and tactical), which ultimately directed specific action. The NIM, therefore, set out a framework for British police forces to follow.

Compliance of the model was tested and enforced. This meant, with the NIM as the driving force for operational activity, the police analyst emerged as a key role. Indeed, in the period that followed the role diversified into various forms such as: intelligence; crime; major incident; performance; partnership; counter terrorist; and business analyst, to name but a few. Analysts also became dedicated to specific themes, from child sexual exploitation (CSE) to police misconduct inquiries. However, whilst the environment appeared set for the police analyst to emerge as a core figure, especially given the growing complexity of crime (e.g. cyber-crime, violent extremism and serious and organised crime), many felt this ambition was not realised (Sissens, 2008). The next section will outline the reasons why.

\section{The demise of the police analyst}

Belur and Johnson (2016) comment upon the superficial nature of crime analysis in the UK, a sentiment reiterated in the USA (Santos \& Taylor, 2014). Both studies argued the police

\footnotetext{
${ }^{1}$ In the UK the term 'intelligence product' is synonymous with analysis: it is the output from analysis. Intelligence products should include a level of analytical content, often involving a number of different techniques.
} 
analyst role had not been routinely integrated into policing and was often neglected by operational officers. Wider research offers numerous reasons for this prognosis.

At a fundamental level criticisms highlight the poor quality of the analytical product produced by police analysts. Innes et al. (2005, p. 39) argue crime analysis products, are "better understood as an artefact of the data... rather than providing an accurate representation of any crime problems". Other commentators highlight the descriptive nature of analyst products (Chainey, 2012). Evans and Kebbell (2012) found they lacked objectivity and quality, thereby having a limited impact on operational policing. This was also noted by Cope (2004) who found that analyst products tended to describe problems, with analysts being used merely as "information translators" (2004, p. 188). What these commentators emphasized was that describing the data does not provide an understanding of a problem and therefore makes it difficult to provide an appropriate response. This is especially relevant as crime and anti-social behaviour are generally the symptom of other determinants (Goldstein, 1990; Schuller, 2013). Therefore, if methodologies are insufficiently rigorous or objective (Innes, et al., 2005), then "descriptive problem profiles will not tell [police] something they don't already know" (Chainey, 2012, p. 110). Ultimately this can have a negative impact on the credibility of the analyst and their product.

It remains ambiguous whether these issues are generated by poor recruitment or a lack of investment in analyst development. For instance, Ratcliffe (2004:92), notes that "few analysts have the training or educational opportunities to take an intelligence assessment to the highest level". Evans (2008), citing Sternberg, refers to three key ingredients for analysts. Initially, analysts need to be aware of current research and existing theory. Further, they should be creative to embrace new challenges and crime problems, finally they should have the practical skills to apply their knowledge when solving real world problems. There is concern that analysts recruited into the policing environment do not match these competencies. Indeed, many criticise analyst development as the NIM was accompanied by little academic guidance on how police analysts should conduct their business (Townsley et al., 2011). For example, whilst hypothesis testing was shown by Chainey (2012) to improve analysis, this was an approach used infrequently by many analysts. Further, this and other research (Belur and Johnson, 2016; Townsley, et al., 2011; Sissens, 2008) found analysts key skills are hampered by poor training, particularly in the application of rigorous scientific 
research methods. Innes et al. (2005) found that police analysts did not use rigorous methodologies in developing objective analytical conclusions. In essence, seventeen years after the implementation of the NIM, research in both the UK (Belur \& Johnson, 2016) and the USA (Carter, 2015; Santos \& Taylor, 2014) questions whether police analysts are able to think analytically. This is quite surprising as Santos (2014) demonstrates that crime analysis is an essential component in directing a variety of policing activity.

Other commentators have pointed at the 'process driven nature' of the NIM as constraining effective practice with some arguing the tightly regimented approach leads to unintended consequences (MacVean \& Harfield, 2008). Here, prescribed templates, intelligence products and numerous meetings have neutralised analytical creativity (Chainey, 2012). The analyst became the focus of numerous demands from a variety of police departments, often supporting the routine administration of the tasking and coordination meetings (Ratcliffe, 2004). Belur and Johnson (2016) found that the analyst often had to respond to what police managers warranted current attention which, often tactical in nature, focused on short term issues that did not allow analysts the time to examine crime issues. However, Ratcliffe notes that "good research takes time" (2004, p. 86), with Belur and Johnson (2016, p. 7) adding, "problem profiles take time and police fail to accept the time it takes".

Finally, it should also be noted the organisational culture of the police, which is said to be particularly strong, and often obstructing reform (Chan, 2001), is also said to hinder crime analysis. Specifically, the inability to integrate crime analysis into mainstream policing, and the failure to understand or appreciate the analyst role may have inhibited their contribution to policing (MacVean \& Harfield, 2008; Belur \& Johnson, 2016; Santos \& Taylor, 2014).

The impact of all these issues was believed to be compounded following the financial crisis of 2007, which led to enforced austerity measures to public services, including UK law enforcement. Interestingly, MacVean \& Harfield (2008) noted that a failure to appreciate the analyst role would make them vulnerable to efficiency savings and anecdotally resulting in a reduction of analyst numbers. This is important as Evans argues that for the analyst role to have impact, an organisation needs to create a "critical mass" (2008, p. 105). In other words, there needs to be enough analysts to effect change. A reduction in analysts makes that less likely to occur. 


\section{The advent of Evidence Based Policing}

The research so far could be viewed as illustrating a somewhat pessimistic future for police analysts. However, this paper now goes on to explore whether some hope lies in the most recent articulated approach - evidence-based policing - which has been growing internationally in stature. How the evidence that supports Evidence-based policing, (EBP) is evaluated is a subject contested by academics. However, it is not the purpose of this paper to engage in this debate which can be found elsewhere (see Knutsson \& Tompson, 2017). The term EBP derived from evidence-based practices associated with medicine (Lumsden, 2016) and was introduced as a concept for policing when Sherman published Evidence-Based Policing, Ideas in American Policing in 1998. EBP emphasises a more thorough approach to policing research by collaborating with academic institutions and providing rigorous research methodologies to understand crime problems and 'what works' in relation to a policing response. Weisburd and Neyroud (2011) suggest that there has been a disconnect between policing and science. They suggest that "science must become a natural part of police education, and police education must become based in science" (2011, p. 236).

If this approach is to be embraced the role of police analysts could once more become critical. Belur and Johnson (2016) argue analysis in a police setting is weak compared with academic institutions. Whilst the NIM stifled the analyst role, the use of more scientific analyses, many of which underpin EBP approaches, could add value to crime analysis. This could, in turn, also develop and improve crime analysis putting it on par with academic institutions. It is generally agreed that the majority of analyst products are too descriptive. If the analyst is afforded more time to conduct detailed analysis, such as develop and test hypotheses, collect wider data sets and use appropriate research methods, they would be in a better position to understand crime problems. This would also help improve police responses to such problems. Improving the quality of the analytical product should improve the integration of crime analysis within operational policing. Guilfoyle (2015) draws on a variety of research to note "that when richer information is available, decision makers are more likely to engage in behaviours consistent with organizational interests" (2015, p. 197). However, if there is to be an effective paradigm shift in policing then it will need to navigate potential anticipated barriers. 
Lumsden (2016) argues it requires significant support from senior officers, as well as improved understanding by all staff. This is supported by Telep and Lum (2014) who note the first step must be "actually knowing about the philosophy of evidence-based policing approaches" (2014, p. 375), which Lumsden states is currently "patchy" (2016, p. 9). Early adopters of evidence-based policing have highlighted a number of ways to raise awareness, such as EBP Café's (Clough, et al., 2017), investing in police "pracademics" (Braga, 2016, p. 311) as internal consultants or embedding criminologists in law enforcement departments (Braga, 2013; Petersilia, 2008). Petersilia (2008) argues that academics and their scientific knowledge would be instrumental in understanding crime and influencing policy. This would certainly help promote the development of 'police science' as proposed by Weisburd and Neyroud (2011), who argue that the police need to own their research. Crawford (2017), reticent to the police leading on developing EBP, prefers that "collaborative research partnerships built on relationships" (2017, p. 210) would improve evidence through co-production. Interestingly, Santos and Santos (2015) have started to implement 'Stratified Policing' in a number of US police forces as a means of integrating crime analysis more efficiently. This innovative approach is aimed at improving the use and acceptance of EBP in American police forces through changing internal frameworks that encourage the use of different levels of EBP.

The article now moves on to discuss the methodology. First, to establish the current status of the police analyst within the UK and secondly to examine whether EBP provides opportunity for the future of this role, or whether its status will decline.

\section{METHODOLOGY}

The methodology is in two parts. The first stage examines whether there is any evidence to support the anecdotal comments that police analyst posts have been reduced. The second stage examines analyst perspectives in relation to evidence based policing.

The first stage involved a survey with several UK police forces in relation to changes in analyst posts. The survey was circulated to the eight police agencies in the 'most similar groups' aligned to the Constabulary to which one of the authors is aligned to. All 43 police forces in England and Wales, are clustered into their 'most similar group' (MSG), based on 
demographic, economic and social characteristics, relating to crime ${ }^{2}$. The purpose for using MSGs is documented as:

"MSGs are designed to help make fair and meaningful comparisons between [police] forces. Forces operate in very different environments and face different challenges. It can be more meaningful to compare a force with other forces which share similar social and economic characteristics, than, for example, a neighbouring force. The development of the MSG approach involved stakeholders from the Home Office, Association of Chief Police Officers and HMIC, with advice from independent academics." ${ }^{3}$

The second stage involved a survey of police analysts. The survey comprises a set of ten questions, with the first five asking for participant details about their role and then five more questions related to their work (see appendix). It sought to understand if analysts had any knowledge of EBP, if they had been trained in its use and if they were using EBP to direct crime analysis. The survey was pilot-tested with a group of 17 analysts from a single force before going live to a national group of participants.

The distribution plan involved the use of the National Analyst Working Group (NAWG) ${ }^{4}$ email list with permission from the NAWG. There was a total of 143 email addresses and non-police service emails were removed. This resulted in a 103 email addresses and included all police forces of England and Wales. The survey was open for 31 days allowing respondents ample time to complete the survey. All respondents included in the analysis for this paper had completed this survey within 13 days of the request.

\section{Limitations of the study}

It is recognised this is a small study and the method would not necessarily elicit a representative or random sample (Rees, 2000) in relation to analyst posts or experience of EBP. Specifically, in relation to the EBP survey, 23 (68\%), of respondents were weighted towards analyst management, with only $10(29 \%)$ of respondents being practitioners. It could

\footnotetext{
${ }^{2}$ Details are online at https://www.justiceinspectorates.gov.uk/hmic/crime-and-policingcomparator/about-the-data/

${ }^{3}$ Ibid: "Why use Most Similar Groups?"

${ }^{4}$ The NAWG is a group of UK analysts, mostly analyst supervisors, who are dedicated to promoting the analyst role within law enforcement agencies.
} 
be argued that analyst managers are engaged with improving analysis so will be supportive of any approach aimed at improving analysis. The overall response rate was low with only 34 respondents $(33 \%)$ completing the survey. This may be indicative of time available to potential respondents. Future studies should perhaps consider a longer 'window of opportunity' for similar surveys and send reminders to the distribution list. However, this paper can act as a starting point and guide future research in examining the value of EBP and the role of the police analyst.

\section{RESULTS}

\section{Stage 1}

Five $(62 \%)$ of the eight police forces responded to the request for analyst information. Those who responded highlighted a reduction of analyst posts that ranged between $28 \%-50 \%$ during a five-year period (see table 1) when the UK introduced budget cuts to the public sector (the numbers do not include counter terrorism analyst posts). This supports anecdotal reports and is thought to be representative of the UK policing landscape.

Table 1. Changes in analyst volume in one 'most similar group of police forces' (2011 to 2016).

\begin{tabular}{|l|r|r|r|}
\hline \multirow{2}{*}{ Force } & \multicolumn{2}{|c|}{ Analyst numbers } & \multirow{2}{*}{$\%$ change } \\
\cline { 2 - 4 } & Pre-cuts & Post-cuts & \\
\hline A & 40 & 20 & $-50 \%$ \\
\hline B & 16 & 10 & $-38 \%$ \\
\hline C & 37 & 26 & $-30 \%$ \\
\hline D & 47 & 27 & $-43 \%$ \\
\hline E & 25 & 18 & $-28 \%$ \\
\hline
\end{tabular}

\section{Stage 2}

The 10-question survey was voluntarily completed by $34(33 \%)$ of respondents who represented 22 (51\%) of the 43 police forces of England and Wales. All respondents were civilian police staff and 23 (68\%) were female. Respondents were roughly split into three 
distinct areas of seniority: 10 (29\%) were analyst practitioners; six (18\%) were senior analysts (first line supervisors); 17 (50\%) were classed as a head of service (e.g. Head of Analysis); and there was one analyst trainer. $31(91 \%)$ of the respondents had over 10 years' experience within crime analysis, with 25 (73\%) benefitting from higher education (12 graduate, 12 postgraduate and 1 Ph.D).

Respondents were initially asked what input they had received regarding EBP and what they considered their level of knowledge of EBP was. Half $(50 \%, n=17)$ reported receiving informal input', whilst 15 (44\%) disclosed receiving a 'professional development session'. Only two (6\%) of the respondents reported not receiving any form of input, and both were unsure whether it could help improve the analyst role. All respondents reported some level of knowledge of EBP. 'Reasonable knowledge' ( $n=12,35 \%)$ was the most common response followed by 'basic knowledge' ( $n=11,32 \%)$. Of the six (18\%) who claimed to have detailed knowledge of EBP, all were managers (listed as department head).

In relation to the use of EBP there was a diversity of answers. Six (18\%) respondents noted they never use EBP approaches, with nine (26\%) noting they rarely use EBP. Conversely, seven respondents (21\%) reported they used EBP approaches 'some of the time' with a further seven, 'most of the time'. Of the two (6\%) respondents who claimed to use EBP approaches 'all of the time' both were in a senior management roles and had disclosed a 'reasonable knowledge of EBP'. Specific comments in relation to this question included: "I have commissioned EBP work" (R345), "we followed the optimal forager model but changed it as results were negligible" (R25), and "[I] have had formal training and intend to use it more" (R20).

It was clear that the majority of respondents $(n=25,73 \%)$ believe that a greater use of EBP could improve their analysis. Four (12\%) respondents did not believe that EBP could improve their analysis and three (9\%) did not know either way. It was interesting to note that of the four respondents who did not think EBP could improve their analysis, two were practicing analysts and two were heads of service. Furthermore, all four had received some level of input (2=informal input and $2=$ professional development). In relation to using EBP, two

\footnotetext{
${ }^{5} \mathrm{R}$ refers to respondent number in the survey returns.
} 
respondents reported never using EBP and one noted that they used it rarely, with one claiming to use it all the time.

Respondents were further questioned as to why they did not use EBP approaches to uncover potential obstacles in the use of EBP. There were only $19(56 \%)$ respondents who answered the final question, with four respondents noting multiple reasons. Answers included:

I don't consider it necessary $(n=2,10 \%)$

- I don't have the time $(n=3,16 \%)$

I don't have the resources $(n=5,26 \%)$

I don't know how to conduct this type of research $(n=6,31 \%)$

It's not part of the terms of reference $(n=1,5 \%)$

Additionally, seven (37\%) respondents added more detail regarding obstacles in the free text option of the final question. A couple of respondents (R24 and R28) noted that they had neither the time, the capacity or resources in engage in EBP. Whilst another respondent noted that, "it's not part of the culture in our force" (R25). The respondent (R25) added that there was no time and "no appreciation of outside research". Other responses included the following reasons for not using EBP in their role: "reactive jobs and no opportunity to use [EBP]" (R2), "limited access to wider academic sources" (R17), "department is currently undergoing a restructure and I don't have the resources, but it is my intention to build in the capacity to do so in the future" (R7) and one noted that their role was "more managerial" (R23).

\section{DISCUSSION}

This paper has illustrated mixed fortunes for the police analyst. It commenced in optimistic fashion with the emergence of a bright new world in the form of the UK National Intelligence Model at the start of the new millennium. This was a period when crime analysis took centre stage offering new approaches in understanding crime problems. Unfortunately, the expectations for crime analysis did not materialise with the dumbing down of rigorous research and analysis (Belur \& Johnson, 2016). Consequently, research has intimated that the 
lack of quality (for whatever reason) in the analysis product has impacted negatively on the quality of the analyst role. Questions regarding the validity of the analyst soon surfaced (Cope, 2004). This paper has shown that during the five years of reducing UK police budgets (20112016), the five police forces from one MSG, reported between $28 \%$ and $50 \%$ reductions in analyst numbers.

However, although intelligence-led policing has lost some of it kudos there appears no suggestion that policing will return to a reactive approach. EBP has emerged as the latest approach to embed 'what works' and associate the profession with science. If EBP is viewed in its broadest sense, rather than the gold standard of randomised control trials often associated with the medical approach (Knutsson \& Tompson, 2017), EBP should be accessible to mainstream policing. As such it should be able to foster a wide range of methodologies and techniques to improve the quality of decision making, basing it on more rigorous evaluation and understanding. Again, as with intelligence-led policing, the police analyst can act as a catalyst, as both practitioner and consultant, to support the integration of EBP for the wider police organisation. But to do this they will need adequate training and access to appropriate resources, the latter of which has been identified within the survey as a barrier.

The survey of analysts conducted for this paper demonstrates that most respondents were, to some degree, aware of EBP and had some knowledge of it. However, only 16 (47\%) respondents claimed to use EBP in their role on a regular basis. Almost equally, $15(44 \%)$ of respondents claimed that they had never, or rarely, used EBP approaches in their analysis. Despite not all respondents using EBP approaches, most $(n=25,73 \%)$ agreed that using EBP could improve their analysis. The reasons given for its limited use included: not having sufficient resources; limited access to academic sources; not knowing how to conduct that type of research; and the restrictions of police culture.

These results suggest that although the potential is present for police analysts to be central to the EBP movement, several areas will need addressing. There is, at the time of writing, little academic guidance in developing analytical methodologies transferable to police analysts, and if EBP is to be embedded this element needs to improve (Townsley, et al., 2011; Dawson \& Williams, 2009). The professional development of analysts should be a priority (Evans, 2008) and perhaps having appropriately trained analysts in a pracademic role will smooth the integration of EBP into crime analysis, with the results being two-fold: improving 
the quality of the analyst products (Santos, 2014) and integrating crime analysis more effectively into routine police practice (Belur \& Johnson, 2016; Santos \& Taylor, 2014). Whilst EBP as an approach encompasses more than just the role of analyst, the police analyst can develop analysis for the wider policing benefit. The theory of evidence-based policing is sound and there is general support to progress its integration into policing practice. However, the practical application is not so clear and there are anticipated issues with implementation, as one survey participant noted, "it is not part of the culture in our force" (R25). There is a long history of implementation failure in policing (Kirby, 2013) and it has been suggested that the police may need to slow down in order to speed up (Constable, 2017). Indeed, if EBP is to be a co-production effort between academic institutions and the police then there needs to be some reconciliation between "competing time horizons" (Crawford, 2017, p. 210). However, there appears to be an appetite generally within policing to accept EBP, despite a number of opinions on how best to do this.

\section{CONCLUSION}

The literature review presented here has shown a contrast in the fortunes of the police analyst, which has ultimately hindered the integration of crime analysis into policing. Key features have included a dearth in training, rigid structures, a lack of time and resources. Similar issues were noted in the analyst survey conducted in this study. The evolution of the analyst as an essential professional within modern UK policing has been stunted by the very business model, the NIM, that sought to improve its role. Research has shown that crime analysis is still trying to find its niche (Belur \& Johnson, 2016; Santos, 2014) and the growing stature of EBP may be an opportunity to carve this out.

The MSG survey findings reveal that analyst numbers have reduced, but despite this, research continues to emphasise the importance of crime analysis (Santos, 2014). Furthermore, there is a clear rationale to promote the use of EBP as a positive step to improve crime analysis. If the police are to move forward and embrace a more methodological approach to crime analysis they need will need qualified people to do so. This means police forces need to invest in appropriate resources (Evans, 2008) and improve their use of scientific research (Dawson \& Williams, 2009). This should also take account of how policing can integrate policing experience as an evidence base as noted by Roach and Pease (2017). Indeed, Sherman and 
Murray (2015) also note that police professionals have added major contributions to policing research.

Findings from the analyst survey has clearly shown that they believe the use of EBP can improve their role and their products. However, to fulfil this belief analysts will need to have knowledge of appropriate theory and establish processes that combines data, framed by theory, to develop inferences and conclusions, all of which would improve the scientific rigour of their work (Townsley, et al., 2011).

This paper supports the notion that analysts should have access to appropriate resources, be trained in EBP and allowed the time to conduct research as it will improve the quality of their products (Chainey, 2012; Townsley, et al., 2011) and their integration within policing. Perhaps the police analyst role can be trained to become a pracademic as envisioned by Braga (2016) and instrumental in developing a 'police science' (Weisburd \& Neyroud, 2011). Integrating EBP, in its widest sense, could be the kick-start analysts and crime analysis needs. 


\section{APPENDIX}

\begin{tabular}{|c|c|c|}
\hline & Participant details / survey questions & Variables \\
\hline \multirow{3}{*}{1} & \multirow{3}{*}{ Employment: } & Police staff \\
\hline & & Police officer \\
\hline & & Other \\
\hline \multirow{9}{*}{2} & \multirow{9}{*}{ Current role: } & Intelligence analyst \\
\hline & & Crime analyst \\
\hline & & Partnership analyst \\
\hline & & Major crime analyst \\
\hline & & Business analyst \\
\hline & & Researcher \\
\hline & & Senior analyst \\
\hline & & Head of analysis \\
\hline & & Other \\
\hline \multirow{2}{*}{3} & \multirow{2}{*}{ Gender } & Male \\
\hline & & Female \\
\hline \multirow{7}{*}{4} & \multirow{7}{*}{ Length of service: } & 2 years or less \\
\hline & & More than 2 years, but less than 5 years \\
\hline & & 5 years or more, but less than 10 years \\
\hline & & 10 years or more, but less than 15 years \\
\hline & & 15 years or more, but less than 20 years \\
\hline & & 20 years or more, but less than 30 years \\
\hline & & 30 years or more \\
\hline \multirow{7}{*}{5} & \multirow{7}{*}{ Educational level: } & No qualifications \\
\hline & & GCSE, O Level or equivalent \\
\hline & & A level , BTEC or equivalent \\
\hline & & Undergraduate \\
\hline & & Postgraduate (MA, MSc..) \\
\hline & & $\mathrm{PhD}$ \\
\hline & & Other \\
\hline \multirow{6}{*}{6} & \multirow{6}{*}{$\begin{array}{l}\text { Have you had any training, professional } \\
\text { input or informal discussions regarding } \\
\text { Evidence-Based Policing? }\end{array}$} & None \\
\hline & & Yes - informal input \\
\hline & & Yes - I have attended a professional development session \\
\hline & & Yes - I have had specific training on EBP \\
\hline & & Yes - Other \\
\hline & & Don't know \\
\hline \multirow{7}{*}{7} & \multirow{7}{*}{$\begin{array}{l}\text { Which of the following most closely } \\
\text { describes your level knowledge regarding } \\
\text { Evidence-Based Policing? }\end{array}$} & No knowledge of EBP \\
\hline & & Aware of EPB, but very limited knowledge of it \\
\hline & & Basic knowledge of EBP \\
\hline & & Reasonable knowledge of EBP \\
\hline & & Detailed knowledge of EPB \\
\hline & & Don't know \\
\hline & & Other \\
\hline
\end{tabular}




\section{REFERENCES}

Audit Commission (1993). Helping with Enquiries: Tackling Crime Effectively [accessed on 31st May 2017:

http://webarchive.nationalarchives.gov.uk/20150421134146/http:/archive.auditcommission.gov.uk/auditcommission/subwebs/publications/studies/studyPDF/1079.pdf].

Belur, J. and Johnson, S. (2016). Is Crime Analysis at the Heart of Policing Practice? A Case Study. In Policing and Society, 1-19. Published online [accessed on $4^{\text {th }}$ May 2017: http://www.tandfonline.com/doi/full/10.1080/10439463.2016.1262364].

Braga, A. (2016). The Value of 'Pracademics' in Enhancing Crime Analysis in Police Departments. In Policing, 10(3):208-314. Washington, DC: Police Foundation.

Braga, A. (2013). Embedded Criminologists in Police Departments. In Ideas in American Policing, Police Foundation, number 17.

Carter, J.G. (2015). Intelligence Analysis with U.S. Law Enforcement Agencies: Empirical Insights from a National Sample. In Journal of Intelligence \& Analysis, 22(3):1-24.

Chainey, S. (2012). Improving the Explanatory Content of Analysis Products Using Hypothesis Testing. In Policing, 6(2):108-121.

Chan, J. (2001) Negotiating the field: New Observations on the Making of police officers. In The Australian and New Zealand Journal of Criminology, vol. 34 (2):114-133.

Clough, G., Adams, A. and Halford, E. (2017). Evidence Cafés and Practitioner Cafés Supported by Online resources: A Route to innovative training in Practice Based Approaches [accessed on $3 r d$ May 2017: http://www.academia.edu/31529842/Evidence_Caf\%C3\%A9s_and_Practitioner_Caf\%C3\%A 9s_supported_by_online_resources_A_route_to_innovative_training_in_practice_based_ap proaches].

Constable, N. (2017). "I recommend a course of leeches": The Problem with Evidence-Based Policing. In Policing Insight, 26 th $^{\text {th }}$ April 2017. https://policinginsight.com/opinion/irecommend-course-leeches-problem-evidence-based-policing/ [accessed 3rd May 2017].

Cope, N. (2004). Intelligence Led Policing or Policing Led Intelligence? Integrating Volume Crime Analysis into Policing. In British Journal of Criminology, 44(2):188-203. 
Crawford, A. (2017). Research Co-production and Knowledge Mobilisation in Policing. In Knutsson, J. and Tompson, L. (2017). Advances in Evidence-Based Policing. Oxon: Routledge, pp.195-213.

Dawson, P. and Williams, E. (2009). Reflections from a Police Research Unit - An Inside Job. In Policing, 3(4):373-380.

Evans, J.M. and Kebbell, M.R. (2012). The Effective Analyst: A Study of What Makes an Effective Crime and Intelligence Analyst. In Policing and Society, 22(2):204-219.

Evans, M. (2008). Cultural Paradigms and Change: A Model of Analysis. In Harfield, C., MacVean, A., Grieve, J. and Phillips, D. (2008). The Handbook of Intelligent Policing. Oxford: Oxford University Press, pp. 103-109.

Goldstein, H. (1990). Problem-Oriented Policing. New York: USA, McGraw-Hill, Inc.

Goldstein, H. (1979). 'Improving Policing: A Problem-Oriented Approach.' In Crime and Delinquency, 25(2):236-258.

Guilfoyle, S. (2015). Binary Comparisons and Police Performance Measurement: Good or Bad? In Policing, 9(2):195-209.

Innes, M., Fielding, N., and Cope, N. (2005). The Appliance of Science? The Theory and Practice of Criminal Intelligence Analysis. In The British Journal of Criminology, 45(1):39-57.

John, T., \& Maguire, M. (2003). Rolling out the NIM: key challenges. In K. Bullock \& N. Tilley (eds). Crime Reduction and Problem-oriented Policing. Cullompton, Willan: pp.38-68

Kelling, G.L., Pate, T., Dieckman, D. and Brown, C.E. (1974). The Kansas City Preventative Patrol Experiment. In Klockars, C.B and Mastrofski, S.D. (1991). Thinking About Policing: Contemporary Readings, Second Edition. New York: McGraw-Hill, pp. 139-163.

Kirby, S. (2013). Effective Policing?: Implementation in Theory and Practice. Palgrave: Macmillan.

Knutsson, J. and Tompson, L. (2017). Advances in Evidence-Based Policing. Oxon, Routledge. Lumsden, K. (2016). Police Office and Civilian Staff Receptivity to Research and EvidenceBased Policing in the UK: Providing a Contextual Understanding through Qualitative Interviews. In Policing, 11(2):157-167. 
MacVean, A. and Harfield, C. (2008). Science or Sophisty: Issues in Managing Analysts and Their Products. In Harfield, C., MacVean, A., Grieve, J. and Phillips, D. (2008). The Handbook of Intelligent Policing. Oxford: Oxford University Press, pp. 93-105.

NCIS (National Criminal Intelligence Service). (2000). The National Intelligence Model. London: NCIS.

Pease, K. and Roach, J. (2017). How to Morph Experience into Evidence. In Knutsson, J. and Tompson, L. (2017) Advances in Evidence-Based Policing. Oxon: Routledge, pp. 84-99.

Petersilia, J. (2008). Influencing Public Policy: An Embedded Criminologist Reflects on California Prison Reform. In Journal of Experimental Criminology, 4(4):335-356.

Ratcliffe, J. (2004). Intelligence Research. In Ratcliffe, J. (Ed.) Strategic Thinking in Criminal Intelligence. Sydney, Federation Press: pp. 86-98.

Rees, D.G. (2000). Essential Statistics, Third Edition. London: Chapman \& Hall/CRC.

Santos, R. and Santos, R.B. (2015) Evidence-Based Policing, "What Works" and Stratified Policing, "How to Make it Work". In Translational Criminology, 8, Spring 2015:20-22.

Santos, R.B. (2014). The Effectiveness of Crime Analysis for Crime Reduction: Cure of Diagnosis? In Journal of Contemporary Criminal Justice, 30(2):147-168.

Santos, R.B. and Taylor, B. (2014). Integration of Crime Analysis into Police Work. In Policing: An International Journal of Police Strategies and Management, 37(3):501-520.

Schuller, N. (2013). Is Crime a Question of Health? In Safer Communities, 12(2):86-96.

Sherman, L. and Murray, A. (2015). Evidence-based Policing: From Academics to Professionals. In International Criminal Justice Review, 25(1):7-10.

Sherman, L. (1998). 'Evidence-Based Policing', Ideas in American Policing. Washington: Police Foundation.

Sissens, J. (2008). An Evaluation of the Role of the Intelligence Analyst within the National Intelligence Model. In Harfield, C., MacVean, A., Grieve, J. and Phillips, D. (2008). The Handbook of Intelligent Policing. Oxford: Oxford University Press, pp. 121-131.

Skolnick, J.H., and Bayley, D.H. (1988). Theme and Variation in Community Policing. In Crime and Justice: A Review of Research, Vol. 10(1):1-38. 
Telep, C.W., and Lum, C. (2014). The Receptivity of Officers to Empirical Research and Evidence-Based Policing: An Examination of Survey Data from Three Agencies. In Police Quarterly, 17(4):359-385.

Townsley, M., Mann, M., and Garrett, K. (2011). The Missing Link of Crime Analysis: A Systematic Approach to Testing Competing Hypotheses. In Policing, 5(2):158-171.

Weisburd, D. and Neyroud, P. (2011). Police Science: Toward a New Paradigm. In Journal of Current Issues in Crime, Issues, and Law Enforcement, 7(2):227-246. 
SUGGEST APPENDIX TABLE HERE 